\title{
Underreporting of Fatal Congenital Zika Syndrome, Mexico, 2016-2017
}

\section{Victor M. Cardenas, Angel Jose Paternina-Caicedo, Ernesto Benito Salvatierra}

To determine completeness of fatal congenital Zika syndrome reporting in Mexico, we examined data from the Mexican National Institute of Statistics and Geography. We found that an estimated $50 \%$ more infants died from microcephaly attributable to congenital Zika syndrome during 2016-2017 than were reported by the existing surveillance system.

$\mathrm{C}$ ongenital Zika syndrome (CZS), described in Brazil in 2015, consists of a set of congenital malformations (saliently microcephaly) and an increased risk for stillbirth and early childhood death (1-3). Epidemiologic studies have demonstrated that Zika virus causes CZS (4) and that Zika virus-associated birth defects developed in $\approx 5 \%$ of fetuses and newborns of infected pregnant women $(3,5-7)$.

Rates of reported CZS cases in the Americas vary widely. Most (79\%) of the 3,720 confirmed cases of CZS reported in the Americas as of January 2018 were reported in Brazil (8). The higher reported rates in Brazil could result from the preexisting birth defects registration in Brazil, enhanced by the occurrence of embriopathy associated with use of thalidomide to treat leprosy (9). If the $5 \%$ prevalence of CZS among neonates of infected pregnant women found in population studies $(3,5-7)$ were applied to the 7,113 pregnant women reported in Mexico as being Zika virus infected (10), one would expect $\approx 355$ CZS cases, not the 51 reported as of November 2018 (11).

To improve the public health surveillance and research of CZS, we assessed the effects of the Zika virus epidemic on rates of infant death from microcephaly and estimated the completeness of reporting of fatal CZS cases in Mexico. This study was exempt from institutional review board oversight.

\section{The Study}

We accessed tabulated data on infant deaths and births available from the Mexican National Institute of Statistics

Author affiliations: University of Arkansas for Medical Sciences,

Little Rock, Arkansas, USA (V.M. Cardenas); Universidad Nacional de Colombia, Bogota, Colombia (A.J. Paternina-Caicedo); Unidad

San Cristóbal, Chiapas, Mexico (E.B. Salvatierra)

DOI: https://doi.org/10.3201/eid2508.190106 and Geography for 1998-2017 (12,13). Using the International Classification of Diseases, 10th Revision, we selected records for infants whose underlying cause of death was coded as microcephaly (Q02X). We used the most recent published report of CZS available from the Mexico Ministry of Health Division of Epidemiology (13).

We estimated infant mortality rates by using the number of registered live births per year for the entire country (i.e., cause-specific infant death rates, expressed per 100,000 live births). Because the Zika virus epidemic in Mexico started in November 2015 (14), our exposure period of interest was 2016-2017. We identified the baseline period by using joinpoint trend analysis (15), a statistical method used to decompose temporal trends (annual percent change [APC]) into meaningful segments. We used the permutation test to identify the most parsimonious results (15). We then compared the baseline rate with that of the epidemic period by using the rate ratio and estimating its $95 \%$ CI. Infant deaths possibly resulting from the Zika virus epidemic were estimated by using the attributable risk and compared with the number of fatal CZS cases reported by the existing CZS surveillance system. We tested statistical significance by using normal approximation and set the threshold at $\mathrm{p}=0.05$.

From 1998 through 2017, a total of 467 infants died of microcephaly in Mexico (Table 1). Joinpoint regression identified an overall significant decrease of $6.80 \%$ APC (95\% CI $-11.9 \%$ to $-1.4 \%$ ) for $2007-2015$ and a statistically significant increase of $27.25 \%$ APC for 2016-2017 (95\% CI 3.0\% to 57.2\%) (Figure). On the basis of the results of the trend analysis and the documentation of the first Zika virus outbreak in Mexico during November 2015, we selected the period 2007-2015 as baseline (Table 2).

During the epidemic period (2016-2017), the rate of infant deaths from microcephaly was 1.17 deaths/100,000 live births; during the preceding 4 years (2007-2015), the rate was 0.80 deaths $/ 100,000$ live births. Thus, the rate ratio was 1.5 (95\% CI 1.1-2.0). The attributable risk was 31.7\%.

From January 1, 2016, through November 26, 2018, a total of 51 cases of CZS were reported in Mexico; of these, 11 deaths were reported during 2016-2017. Applying the attributable risk of $31.7 \%$ to the 53 reported infant deaths from microcephaly during 2016-2017, we estimated that $\approx 17$ infant deaths from microcephaly were attributable to the Zika virus epidemic. Compared with the 11 reported 
Underreporting of Congenital Zika Syndrome, Mexico

Table 1. Infant deaths from microcephaly and death rates per 100,000 live births, by year, Mexico, 1998-2018

\begin{tabular}{lccc}
\hline & & & \\
Year & No. infant deaths from microcephaly & $\begin{array}{c}\text { Rate of infant deaths from } \\
\text { microcephaly/100,000 live births }\end{array}$ \\
\hline 1998 & 26 & $2,668,428$ & 0.97 \\
1999 & 24 & $2,769,089$ & 0.87 \\
2000 & 21 & $2,798,339$ & 0.75 \\
2001 & 27 & $2,767,610$ & 0.98 \\
2002 & 23 & $2,699,084$ & 0.85 \\
2003 & 23 & $2,655,894$ & 0.87 \\
2004 & 27 & $2,625,056$ & 1.03 \\
2005 & 31 & $2,567,906$ & 1.21 \\
2006 & 29 & $2,505,939$ & 1.16 \\
2007 & 26 & $2,655,083$ & 0.98 \\
2008 & 22 & $2,636,110$ & 0.83 \\
2009 & 22 & $2,577,214$ & 0.85 \\
2010 & 21 & $2,643,908$ & 0.79 \\
2011 & 27 & $2,586,287$ & 1.04 \\
2012 & 17 & $2,498,880$ & 0.68 \\
2013 & 18 & $2,478,889$ & 0.73 \\
2014 & 13 & $2,463,420$ & 0.53 \\
2015 & 17 & $2,353,596$ & 0.72 \\
2016 & 26 & $2,293,708$ & 1.13 \\
2017 & 27 & $2,234,039$ & 1.21 \\
${ }^{*}$ International Classification & & & \\
\hline
\end{tabular}

fatal cases, this estimate resulted in a ratio of $1.5(95 \% \mathrm{CI}$ $0.9-2.4$ ), indicating that $50 \%$ more infants died of microcephaly caused by CZS than were reported.

\section{Conclusions}

We found evidence that the Zika virus epidemic reversed the declining trend of infant deaths from microcephaly in Mexico and that the number of deaths from microcephaly associated with Zika virus was $50 \%$ higher than that reported by the existing CZS surveillance system. In addition, on the basis of the case-fatality rate of $22 \%$ for reported CZS, at least 79 cases of CZS would have occurred in 20162017. We also observed an increase in the rates of fetal deaths coded as caused by microcephaly in 2016-2017, but we focused our report on infant deaths because the CZS case definition includes only live births.

Our assessment is not without limitations. First, it was limited to fatal CZS and relies on International Classification of Diseases coding. Increased awareness prompted by the Zika epidemic is another potential source of error. Other sources of data such as morbidity (e.g., hospital discharge and other medical records) still need to be evaluated for changes in temporal trends of microcephaly and other manifestations of CZS, such as arthrogryposis, blindness, and deafness. In addition, the accuracy of microcephaly as the underlying cause of death is unknown; microcephaly could have been present among other conditions mentioned in death records but not selected as the underlying cause of death. We believe that death records are prone to underregistration, and yet we found a significant increase in deaths from CZS in the 2 years of the Zika epidemic in Mexico.

Several factors may lead to incomplete reporting of the Zika virus epidemic and CZS. Had primary infection with Zika virus during pregnancy not resulted in CZS,
Zika virus would have gone mostly unnoticed, as do many other arboviral infections (e.g., dengue, chikungunya). For instance, the short duration of viremia (3-5 days) complicates confirmatory testing. Although obtaining and testing paired serum specimens would provide more certainty, doing so is logistically harder to achieve. Furthermore, the fact that CZS can occur as a result of Zika virus subclinical infection precludes suspicions and testing.

Reporting of communicable diseases in Mexico, as in other countries, is far from complete. In 1981, we found 2 cases of poliomyelitis for every reported case, and in 1989, we found 1 recorded neonate death from tetanus for every 50 such deaths. However, a good surveillance system does not need to achieve complete reporting to be useful; rather, it should accurately depict the patterns of occurrence of the events or conditions of interest that can lead to their control, presuming existence of effective prevention and control methods.

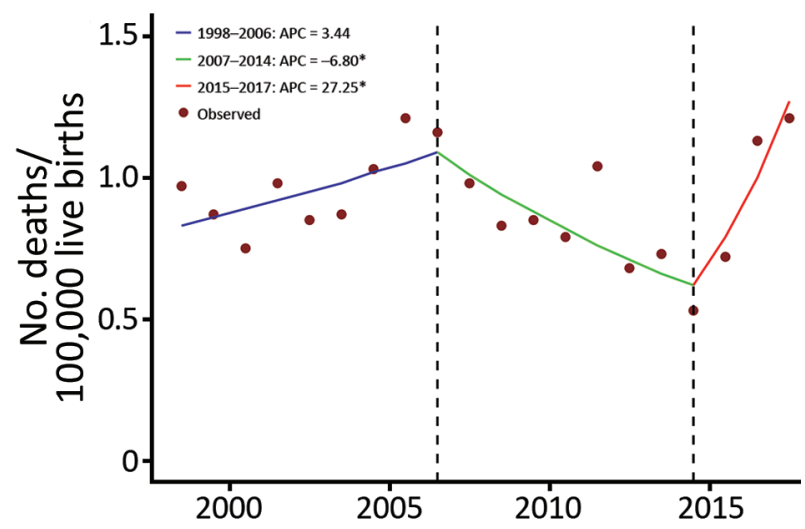

Figure. Infant deaths from microcephaly in Mexico, 1998-2017. APC, annual percent change. ${ }^{*} p<0.05$. 
Table 2. Infant deaths from microcephaly in Mexico during 2007-2015 and 2016-2017

\begin{tabular}{lcccc}
\hline Period & $\begin{array}{c}\text { No. infant deaths from } \\
\text { microcephaly }\end{array}$ & No. live births & $\begin{array}{c}\text { Rate of infant deaths from } \\
\text { microcephaly/100,000 live births }\end{array}$ & Rate ratio (95\% Cl) \\
\hline $2016-2017$ & 53 & $4,527,747$ & 1.17 & $1.5(1.1-2.0)$ \\
$2007-2015$ & 183 & $22,893,387$ & 0.80 & Referent \\
\hline${ }^{*}$ International Classification of Diseases, 10th Revision, code Q02x. & & & \\
\hline
\end{tabular}

To improve Zika virus and CZS surveillance in Mexico, resources could be more efficiently used. Zika-endemic areas could be targeted, using active surveillance to monitor the occurrence of microcephaly at birth and flagging neonates born with gestational age and gender-specific head circumference $<2$ SDs of the reference. The surveillance system could use sentinel sites selected according to the existing risk stratification strategies used for dengue, which could enable extrapolation of the data to the rest of the country. These data would be particularly helpful in $\mathrm{Ae}$ des aegypti mosquito surveillance and control, which represents an enormous public health challenge.

\section{Acknowledgments}

We thank Irma Cardenas for her critical review of the manuscript and Cuitláhuac Ruiz Matus for his enthusiastic support.

\section{About the Author}

Dr. Cardenas is an associate professor of epidemiology at the University of Arkansas for Medical Sciences. He is currently conducting research on the role of environmental factors such as Zika virus and electronic cigarettes on pregnancy outcomes.

\section{References}

1. Schuler-Faccini L, Ribeiro EM, Feitosa IM, Horovitz DD, Cavalcanti DP, Pessoa A, et al.; Brazilian Medical Genetics Society-Zika Embryopathy Task Force. Possible association between Zika virus infection and microcephaly_Brazil, 2015. MMWR Morb Mortal Wkly Rep. 2016;65:59-62. http://dx.doi.org/ 10.15585/mmwr.mm6503e2

2. Miranda-Filho DB, Martelli CM, Ximenes RA, Araújo TV, Rocha MA, Ramos RC, et al. Initial description of the presumed congenital Zika syndrome. Am J Public Health. 2016;106:598-600. http://dx.doi.org/10.2105/AJPH.2016.303115

3. Brasil P, Pereira JP Jr, Moreira ME, Ribeiro Nogueira RM, Damasceno L, Wakimoto M, et al. Zika virus infection in pregnant women in Rio de Janeiro. N Engl J Med. 2016;375:2321-34. http://dx.doi.org/10.1056/NEJMoa1602412

4. de Araújo TVB, Ximenes RAA, Miranda-Filho DB, Souza WV, Montarroyos UR, de Melo APL, et al.; investigators from the Microcephaly Epidemic Research Group; Brazilian Ministry of Health; Pan American Health Organization; Instituto de Medicina Integral Professor Fernando Figueira; State Health Department of Pernambuco. Association between microcephaly, Zika virus infection, and other risk factors in Brazil: final report of a case-control study. Lancet Infect Dis. 2018;18:328-36. http://dx.doi.org/10.1016/S1473-3099(17)30727-2
5. Shapiro-Mendoza CK, Rice ME, Galang RR, Fulton AC, VanMaldeghem K, Prado MV, et al.; Zika Pregnancy and Infant Registries Working Group. Pregnancy outcomes after maternal Zika virus infection during pregnancy-U.S. Territories, January 1, 2016-April 25, 2017. MMWR Morb Mortal Wkly Rep. 2017;66:615-21. http://dx.doi.org/10.15585/mmwr.mm6623e1

6. Honein MA, Dawson AL, Petersen EE, Jones AM, Lee EH, Yazdy MM, et al. Birth defects among fetuses and infants of US women with evidence of possible Zika virus infection during pregnancy. JAMA. 2017;317:59-68. http://dx.doi.org/10.1001/ jama.2016.19006

7. Hoen B, Schaub B, Funk AL, Ardillon V, Boullard M, Cabié A, et al. Pregnancy outcomes after ZIKV infection in French territories in the Americas. N Engl J Med. 2018;378:985-94. http://dx.doi.org/10.1056/NEJMoa1709481

8. Pan American Health Organization. Zika cumulative cases [cited 2019 Jan 15]. https://www.paho.org/hq/index.php?option=com content\&view=article\&id=12390:zika-cumulative-cases\&Itemid= 42090\&lang=en

9. Castilla EE, Ashton-Prolla P, Barreda-Mejia E, Brunoni D, Cavalcanti DP, Correa-Neto J, et al. Thalidomide, a current teratogen in South America. Teratology. 1996;54:273-7. http://dx.doi.org/10.1002/(SICI)1096-9926(199612)54:6<273:: AID-TERA1>3.0.CO;2-\#

10. Dirección General de Epidemiología. Casos confirmados autóctonos de enfermedad por virus Zika en mujeres embarazadas, por entidad de infección, México 2015-2018 [cited 2019 Jan 3]. https://www.gob.mx/cms/uploads/attachment/file/424933/ Cuadro_Casos_ZIKA_y_Emb_sem_51_2018.pdf

11. Instituto Nacional de Estadística y Geografía. Defunciones generals [cited 2019 Jan 3]. https://www.inegi.org.mx/sistemas/ olap/proyectos/bd/continuas/mortalidad/mortalidadgeneral. asp? $\mathrm{s}=\mathrm{est} \& \mathrm{c}=11144 \&$ proy $=$ mortgral $\mathrm{mg}$

12. Instituto Nacional de Estadística y Geografía. Nacimientos [cited 2019 Jan 3]. https://www.inegi.org.mx/temas/natalidad/

13. Secretaría de Salud. Casos confirmados de síndrome congénito asociado a Zika, México 2016-2018 [cited 2019 Jan 3]. https://www.gob.mx/cms/uploads/attachment/file/415187/ Cuadro_Sx_Cong_nito_asociado_a_Zika_26112018.pdf

14. Guerbois M, Fernandez-Salas I, Azar SR, Danis-Lozano R, Alpuche-Aranda CM, Leal G, et al. Outbreak of Zika virus infection, Chiapas State, Mexico, 2015, and first confirmed transmission by Aedes aegypti mosquitoes in the Americas. J Infect Dis. 2016;214:1349-56. http://dx.doi.org/10.1093/infdis/ jiw302

15. Kim HJ, Fay MP, Feuer EJ, Midthune DN. Permutation tests for joinpoint regression with applications to cancer rates. Stat Med. 2000;19:335-51. http://dx.doi.org/10.1002/(SICI) 1097-0258(20000215)19:3<335::AID-SIM336>3.0.CO;2-Z

Address for correspondence: Victor M. Cardenas, University of Arkansas for Medical Sciences, Department of Epidemiology, Fay W. Boozman College of Public Health, 4301 West Markham, \#820, Little Rock, AR 72205, USA; email: vmcardenas@uams.edu 